\title{
Changes in Carbon Stocks and Chemical Attributes of an Oxisol as a Result of Adoption Period of No-tillage System in the Brazilian Eastern Amazon
}

\author{
Edilson Carvalho Brasil \\ Embrapa Eastern Amazon, 66095-903, Belém, Pará, Brazil. \\ E-mail: edilson.brasil@embrapa.com
}

Rubia Carla Ribeiro Dantas (Corresponding author)

Federal Rural University of Amazon, 066.077-830, Belém, Pará, Brazil.

E-mail: ribeirorubiaa8@gmail.com

\begin{abstract}
Mário Lopes da Silva Júnior
Federal Rural University of Amazon, 066.077-830, Belém, Pará, Brazil.

E-mail: mario.silva_junior@yahoo.com.br
\end{abstract}

Luis de Souza Freitas

Federal Rural University of Amazon, 68625-970, Paragominas, Pará, Brazil.

E-mail: luisufra@gmail.com

Received: Dec. 6, 2019

doi:10.5296/jas.v8i3.15988
Accepted: Feb. 3, 2020

Published: Feb. 11, 2020

URL: https://doi.org/10.5296/jas.v8i3.15988

\begin{abstract}
The conversion of forest areas to grain cropping has promoted a decrease in soil organic matter stocks in the Amazon. This process is most striking when the conventional cultivation system is used. In order to evaluate the changes in soil carbon and nutrient stocks resulting from the time of adoption of the no tillage system in a dystrophic Yellow Oxisol of the Brazilian Amazon biome, a study was conducted in a grain producing area in the northeastern of Pará, Brazil. The treatments corresponded to the following systems: CT6- conventional tillage system with six years of implementation; No-tillage system with 3 (NT3), 4 (NT4) and
\end{abstract}


7 (NT7) years of implementation. All systems were always cultivated in corn / soybean rotation. Deformed and non-deformed soil samples were collected on a the 2013 crop year at 0-10, 10-20 and 20-40 cm depths. Stocks of carbon (SC) and phosphorus (P), potassium (K), calcium $(\mathrm{Ca})$ and magnesium $(\mathrm{Mg})$ were calculated by using the equivalent soil mass methodology. Regardless of depth, the NT showed higher SC values than the CT. The adoption of NT showed a tendency of increasing SC of the soil over time. Such increases were up to $36 \%$ of the NT7 compared to the CT6. In NT7, the stocks of K, Ca and Mg were higher in relation to PC6. The EC correlated positively with the stocks of $\mathrm{K}, \mathrm{Ca}$ and $\mathrm{Mg}$ in the areas under NT, regardless of the time of system adoption, up to $40 \mathrm{~cm}$ deep, indicating improvements in the soil fertility.

Keywords: fertility, organic matter, nutrients

\section{Introduction}

Conversion of forests into grain farming in the Amazon has promoted changes in soil organic matter stocks (Deon, 2013). Several factors control the dynamic of soil organic matter (SOM), such as climate, soil texture, vegetation type, soil management, besides the amount and quality of plant residues (Silva et al., 2004; Carvalho et al., 2009a; Mascarenhas et al., 2017).

Soil management systems promote changes in soil carbon (C) stocks, which vary due to differentiated production of residues, number of crops, fertilization, methods of soil tillage and crop residue management (Sa et al., 2017; Rangel et al., 2007). Such changes have direct and indirect reflexes on the various soil characteristics, especially the chemical ones, as well as on the organic matter contents (Tavakkoli et al., 2015; Fontana et al. 2006).

Soil management practices based on less tillage and maintenance of residue stand out as a strategy to increase carbon levels by promoting the physical protection of organic matter, with greater aggregate stability (Sá et al., 2004). In this context, the no-tillage system (NT) represents one of the primary advances in the productive process of Brazilian farming as the dynamics of the processes of transformation and accumulation of organic matter as well as the nutrient cycling differ from the conventional cultivation system (Anghinoni, 2007).

Studies have been conducted under Brazilian Amazon conditions to identify alternative systems for grain production (Fontes et al., 2012; Guedes et al., 2012). The climatic conditions in this region may promote changes in carbon dynamics, with a potential reflection on the chemical and physical attributes of soils (Guedes et al., 2012), as the high temperatures over the year and the high rainfall rates result in intensification of the soil microbial activity (Mielniczuk et al., 2003). This environment favors the acceleration of decomposition of organic waste allocated on the soil surface, causing the systematic reduction of initial carbon stocks (Silva \& Machado, 2000).

No-tillage system is still in the consolidation phase in the Amazon as it has been adopted by grain farmers for a short time. Moreover, little is known about the changes caused by carbon stock and its influence on chemical attributes of soils, caused by the increased adoption time of this system in the edaphoclimatic conditions of the region. Therefore, the knowledge of the magnitude of soil organic matter accumulation processes and their relationship in the 
alteration of soil chemical attributes may allow obtaining the best ways to manage soil fertility under NT in the Amazon. Thus, this study has as hypothesis that the NT enhances stocks of soil carbon and nutrients with the implantation time, compared to the conventional system.

The objective of this study was to evaluate the changes in carbon stocks and chemical attributes in an Oxisol as a function of the adoption period of the no-tillage system under succession of corn/soybean crops in Brazilian Eastern Amazon conditions.

\section{Material and Methods}

This work was carried out in the municipality of Paragominas, Southeastern Pará, Brazil, under the coordinates $02^{\circ} 55^{\prime} 24^{\prime \prime} \mathrm{S}$ and $47^{\circ} 34^{\prime} 36^{\prime \prime} \mathrm{W}$ at approximately 200 meters above sea level. The climate in the region is hot and humid, Awi-type according to classification of Köppen (tropical rainy climate, with significant drought period), with annual average temperature of $26.3{ }^{\circ} \mathrm{C}$, annual average rainfall of $1.800 \mathrm{~mm}$, with two seasons, a rainy season, from December to May and another less rainy season from June to November. Relative air humidity is usually $80 \%$ (Bastos et al., 2005). The soil was classified as dystrophic Yellow Oxisol (Oxisol) (Santos et al., 2013), clayey textured, with an average altitude of 200 meters. The predominant original vegetation is classified as submontane dense subperenifolia equatorial forest, also known as terra firme rainforest (Rodrigues et al., 2003; Veloso et al., 1991).

The study was conducted at the beginning of the rainy season in the region, in an area with a history of degraded pasture use and further crop sequence for grain production over the years, using production models in succession with corn and soybean crops, conducted under conventional tillage (CT) and no-tillage (NT) systems. All study areas were initially subjected to the same process of removal of the remaining vegetation, for further implantation of crops under CT and NT whose adoption periods corresponded to three, four and seven years. The areas under NT consisted of a cropping sequence, defined from the establishment of criteria of uniformity of edaphic, topographic and climatic conditions, differing only in the time of implantation of the crops.

The treatments corresponded to the following soil management systems: CT6 - area under conventional tillage system at six years of implementation, cultivated in corn/soybean rotation; NT3 - area under no-tillage system at three years of adoption, cultivated in corn / soybean rotation; NT4 - area under no-tillage system at four years of adoption, always cultivated in corn/soybean rotation; NT7 - area under no-tillage system at seven years of adoption, cultivated in corn / soybean rotation (Table 1). In all areas under no-tillage system, the forage species Urochloa (synonym Brachiaria) ruziziense was used as a cover crop in succession with the crops. 


\section{MInstitute Macrothink}

Table 1. Soil management system, adoption period and particle size fraction in the $0-20 \mathrm{~cm}$ layer in an Oxisol in the municipality of Paragominas, Pará, Brazil

\begin{tabular}{ccccccc}
\hline \multirow{2}{*}{$\begin{array}{c}\text { Soil } \\
\text { management } \\
\text { system }\end{array}$} & $\begin{array}{c}\text { Adoption } \\
\text { Time } \\
\text { (years) }\end{array}$ & $\begin{array}{c}\text { Total area of } \\
\text { plots } \\
\text { (ha) }\end{array}$ & $\begin{array}{c}\text { Coarse } \\
\text { sand }\end{array}$ & $\begin{array}{c}\text { Thin } \\
\text { sand }\end{array}$ & Silt & Total clay \\
\cline { 4 - 7 } CT6 & 6 & 28 & 22 & 51 & 262 & 665 \\
NT3 & 3 & 86 & 14 & 28 & 328 & 630 \\
NT4 & 4 & 75 & 23 & 54 & 316 & 607 \\
NT7 & 7 & 73 & 18 & 30 & 364 & 588 \\
\hline
\end{tabular}

The study areas were selected in plots with different dimensions, containing the evaluated management systems (treatment), as shown in Table 1. In each plot, corresponding to the management systems, random subareas with dimensions of approximately $200 \mathrm{~m}$ were selected. Four $100 \mathrm{~m}$ x 50m divisions (experimental units) were set in each plot, which corresponded to the repetitions.

For the evaluations of this study, soil sampling was carried out in February 2015 in all experimental units by collecting deformed and non-deformed samples at the $0-10 \mathrm{~cm}, 10-20$ $\mathrm{cm}$ and 20-40 cm depths.

Deformed soil samples were collected between the planting rows at equivalent distances and zigzag paths. Fifteen simple samples were collected per depth to compose a composite sample, in which particle size analysis was performed using the pipette method, with mechanical agitation in high rotation apparatus, determinations of soil chemical attributes (carbon, $\mathrm{pH}$, water, $\mathrm{P}, \mathrm{K}, \mathrm{Ca}, \mathrm{Mg}$ ) and estimated $\mathrm{CEC}$ and $\mathrm{V} \%$. Organic carbon (OC) was determined through the Walkey \& Black method. All chemical and physical analyses followed the methodologies described by Teixeira et al. (2017).

Soil density was determined by collecting non-deformed samples using an Uhland auger with $100-\mathrm{cm}^{3}$ stainless steel volumetric rings. In each experimental unit, three small trenches were opened in representative portions of the Experimental Unit, where samples with non-deformed structure were collected at the mentioned depths, in the median portion of the profile of the referred layers.

Stocks of $\mathrm{C}$ and nutrients ( $\mathrm{P}, \mathrm{K}, \mathrm{Ca}$ and $\mathrm{Mg}$ ), expressed as $\mathrm{Mg} \mathrm{ha}^{-1}$, were calculated for each layer in all evaluated soil management systems by multiplying the concentration of each element $(\%)$ by soil density $\left(\mathrm{g} \mathrm{cm}^{-3}\right)$ and by layer thickness $(\mathrm{cm})$. The methodology of equivalent soil mass described by Ellert \& Bettany (1995) was used, which considers the soil mass of the treatments in relation to the soil with the largest mass (control) for the correction 
of the $\mathrm{C}$ and nutrient stocks in each of the evaluated use systems. Thus, to compose the calculation of $\mathrm{C}$ stocks in the $0-10,10-20$ and $20-40 \mathrm{~cm}$ layers, soil densities of $1.39,1.27$ and $1.25 \mathrm{~g} \mathrm{~cm}^{-3}$ were used, respectively. In order to calculate the total stock of $\mathrm{C}$ and nutrient, the sum of the stocks of each sampled soil layer was performed.

The results were submitted to non-parametric statistical analysis by the Kruskal-Wallis test (Zar, 1999) at a 5\% probability level. This test, also denominated Stations variance analysis, does not require the assumption of variable normality nor the need for variance homogeneity between treatments (Bianconi et al., 2008). Whether there was a significant difference between treatments, the Bonferroni multiple comparison test was used at a significance level of 5\% probability. In relation to assessment of the relationship between carbon and nutrient stocks, Pearson's correlation analysis was performed at 5\% probability.

\section{Results and Discussion}

\subsection{Soil Density}

In the topsoil $(0-10 \mathrm{~cm})$, the no-tillage system (NT) at four years of adoption, on average, had the highest value of soil density (Table 2), indicating a higher surface density that can be attributed to machine traffic intensification associated with the lesser contribution of organic matter, due to the short time of adoption of this system, in relation to the conventional system. This behavior was also observed by Pragana et al. (2012), who attribute to the few years of cultivation under NT (four years), mentioning that there was not enough time for recovery of the soil previously cultivated under CT. However, at seven years of adoption of NT, there was a reduction in soil density values in the topsoil, reaching values close to the system with shorter land use (NT3), which may be associated with higher accumulation of matter over the period in which the system has been adopted. Similar behavior was observed by Rossetti \& Centurion (2015), in which the increased adoption time of NT favored a slight reduction in density in the $0-10 \mathrm{~cm}$ layer of a typical dystrophic Red Oxisol, medium texture. According to Costa et al. (2004), the non-revolving of the soil and the addition of crop residues to the topsoil trigger several interrelated physical, chemical and biological processes that result in increased aggregate stability and organic matter stocks in the soil. According to Assis \& Lanças (2005), the increase in the adoption period in the no-tillage system favored a reduction in soil density at the $0-5 \mathrm{~cm}$ dept. In a study conducted on the same soil type and in the same region of this study, Guedes (2009) found that the contribution of organic matter to improve soil physical properties occurs after 5 years of no-tillage system, in a transition phase, when the accumulation of residues begins on the topsoil and the particles undergo the process of reaggregation. At $10-20 \mathrm{~cm}$ depth, regardless of the adoption period, the highest values of soil density were found in the no-tillage system area, which were higher than the conventional system (CT). For Pragana et al. (2012), the soil under NT receives less traffic and as it does not go through the revolving process, it tends to promote greater surface compaction. According to Tormena et al. (2004), one of the limitations of the use of NT in soils of clayey and very clayey texture is the compaction of the superficial layers, indicating the adoption of periodic soil tillage practices. Rossetti \& Centurion (2015) also obtained higher soil density values in NT areas at seven and nine years of implantation, therefore 
evidencing the repercussion of the natural densification in the deeper layers of the soil, due to non-revolving and compaction caused by traffic of machines in the NT. It was found in the $20-40 \mathrm{~cm}$ layer, the same behavior found in the $10-20 \mathrm{~cm}$ layer, therefore evidencing the effect of the use of machines and the non-revolving of the soil in the increment of the density in deeper layers a no-tillage system.

Table 2. Soil density $\left(\mathrm{g} \mathrm{cm}^{-3}\right)$ of management system of soil in three depths in an Oxisol in the municipality of Paragominas, Pará, Brazil

\begin{tabular}{ccccc}
\hline & \multicolumn{4}{c}{ Management system of soil } \\
\cline { 2 - 5 } Depths $(\mathrm{cm})$ & $\mathrm{CT} 6$ & NT3 & NT4 & NT7 \\
\hline $0-10$ & $1.30 \mathrm{~b}$ & $1.29 \mathrm{~b}$ & $1.39 \mathrm{a}$ & $1.31 \mathrm{~b}$ \\
$10-20$ & $1.23 \mathrm{~b}$ & $1.27 \mathrm{a}$ & $1.26 \mathrm{ab}$ & $1.26 \mathrm{ab}$ \\
$20-40$ & $1.22 \mathrm{a}$ & $1.22 \mathrm{a}$ & $1.25 \mathrm{a}$ & $1.25 \mathrm{a}$ \\
\hline
\end{tabular}

*Means followed by the same letter in the same line are not different by the multiple comparison test of Bonferroni at 5\% probability level.

\subsection{C content and Stock in the Soil}

At all depths, the soil organic carbon (OC) contents in the areas under NT did not differ significantly from each other, but were higher than the area under conventional planting - CT (Table 3). These results can be attributed to the fact that $\mathrm{CT}$ promotes rapid OM oxidation, with loss of native CO, due to soil tillage and harrowing practices (Cavalcante et al., 2007). Petter et al. (2017), in studies conducted in southern Brazilian Amazon, show that long-term carbon losses can contribute significantly to the accumulation of $\mathrm{CO}_{2}$ in the atmosphere and also undermine the sustainability of agricultural production in the Amazon, with direct consequences for exchangeable base levels and cation exchange capacity, since total organic carbon is directly related to these attributes in these soils. In a clayey Yellow Oxisol in the city of Paragominas, state of Pará, Brazil, Chaves (2014) observed that the lowest soil carbon contents were found in a newly implanted area with the crop-livestock integration system, which was initially subjected to plowing and harrowing. The soil carbon values obtained by the author were very similar to those obtained in this work, in an area under conventional system. On the other hand, minimal soil tillage, quantity and quality of rotating crop residues and cover crops over the years promote the gradual increase of organic matter content through the continued use of NT, especially in the topsoil. 
Table 3. Content and stock of carbon in three depths of an Oxisol under conventional tillage and non-conventional system at three, for and seven years of adoption in the municipality of Paragominas, Pará

\begin{tabular}{|c|c|c|c|c|}
\hline \multirow{2}{*}{ Depths (cm) } & \multicolumn{4}{|c|}{ Management system of soil } \\
\hline & CT6 & NT3 & NT4 & NT7 \\
\hline & \multicolumn{4}{|c|}{ soil carhon $\left(\mathrm{g} \mathrm{kg}^{-1}\right)$} \\
\hline $0-10$ & $20.96 \mathrm{~b}$ & $25.10 \mathrm{a}$ & $25.12 \mathrm{a}$ & $25.63 \mathrm{a}$ \\
\hline $10-20$ & $16.97 \mathrm{~b}$ & $20.31 \mathrm{ab}$ & $20.71 \mathrm{ab}$ & $22.08 \mathrm{a}$ \\
\hline $20-40$ & $12.75 b$ & $16.78 \mathrm{a}$ & $16.89 \mathrm{a}$ & $19.71 \mathrm{a}$ \\
\hline & &.$\quad r$ & $2 \cdot-1$ & \\
\hline $0-10$ & $29.13 b$ & $34.89 \mathrm{a}$ & $34.92 \mathrm{a}$ & $35.63 \mathrm{a}$ \\
\hline $10-20$ & $21.55 \mathrm{~b}$ & $25.79 \mathrm{ab}$ & $26.30 \mathrm{ab}$ & $28.04 \mathrm{a}$ \\
\hline $20-40$ & $31.81 \mathrm{~b}$ & $41.87 \mathrm{a}$ & $42.13 \mathrm{a}$ & $49.17 \mathrm{a}$ \\
\hline $0-40$ & $82.49 \mathrm{~b}$ & $102.55 \mathrm{ab}$ & $103.34 \mathrm{ab}$ & $112.84 \mathrm{a}$ \\
\hline
\end{tabular}

* Means followed by the same letter in the same line are not different by the multiple comparison test of Bonferroni at $5 \%$ probability level.

All areas under NT had soil carbon stock (CS) values higher than the area under NT, regardless of depth (Table 3). By considering all the evaluated layers, the CS ranged from 21.55 to $31.81 \mathrm{Mg} \mathrm{ha}^{-1}$ in the area under CT6 and from 25.79 to $49.17 \mathrm{Mg} \mathrm{ha}^{-1}$ in the NT areas. These results indicate that in areas under conditions of higher rainfall and high temperatures throughout the year, such as the Brazilian Amazon biome, there may be greater accumulation of $\mathrm{C}$ in soil under NT. Carvalho et al. (2009b) obtained divergent results in a study conducted in the Cerrado/Brazilian amazon transition zone, where soil carbon stocks in the 0-30 cm layer under a no-tillage system with four years of implementation generally did not differ significantly in comparison with soil under a traditional system, cultivated with soybean after two years with rice. Maia et al. (2010) indicate that the conditions of higher humidity and temperature are likely to obtain higher rates of decomposition of soil organic matter, causing the reduction in carbon storage, when the traditional cultivation system (CT) is established in cultivated areas after the removal the native Amazon forest flora' the Amazon rainforest.

At all depths, the areas under NT showed a tendency to increase soil CS due to the increase in the system adoption period. However, at three and four years of NT adoption, the CS values 
were very close, indicating that CS slightly increased in the early years of NT implementation compared to the cultivated CT6. However, at seven years of adoption, CS significantly increased in comparison to other treatments, highlighting the importance of the NT adoption period so that it can be reached or approach the system stability, provided by the greater accumulation of organic matter. In a Cerrado area after 12 years of cultivation under NT, Siqueira Neto et al. (2009) observed that soils had largely recovered the initial carbon levels found in native vegetation areas of the region. Such fact highlights the need for long-term studies in Amazon soils to evaluate when the stabilization phase of this system effectively begins. Machado \& Silva (2001) state that the CS depend on the amount of straw, type of crop rotation, soil tillage, climate and doses of fertilizers applied to crops. However, according to the authors, the increase in the amount of OM is initially slow, with larger increments only at six or seven years after the implementation of NT, as observed in the results of this study. For Carvalho et al. (2009a), the annual accumulation of soil carbon may vary regionally depending on climate, soil, management and particularly by the time of conversion of native vegetation areas to agriculture and the NT adoption period.

Considering the $0-40 \mathrm{~cm}$ depth, the differences in CS in the areas under NT compared to the conventional cultivation system (PC6) were 24.3, 25.3 and 36.8\%, respectively, for adoption periods of three, four and seven years. This behavioral pattern may be associated with the constant deposition of plant residues and the absence of soil revolving through tillage, which reduces the exposure of protected $\mathrm{C}$ in the soil aggregates to the action of the microbial population, delaying the decomposition process (Al-Kaisi \& Yin, 2005). Additionally, the increase in soil $\mathrm{C}$ stocks is beneficial for the environment as it removes $\mathrm{CO} 2$ from the atmosphere and contributes to greenhouse effect mitigation (Cerri et al., 2010). According to West \& Post (2002), the conversion of CT6 to NT annually sequesters an average of $0.57 \mathrm{Mg}$ $\mathrm{ha}^{-1}$ carbon and considers NT to be one of the most consistent forms of conservation of cultivation, ensuring that the wide use of this system would sequester substantial amounts of carbon.

\subsection{Nutrient Stocks and Soil Chemical Attributes}

In general, P stocks were higher in the NT system. The average values of P stock in the 0-40 $\mathrm{cm}$ layer were influenced by soil management systems, in which CT6 showed the highest amounts of this nutrient (Table 4). By considering that in the different systems of use the same fertilization practices were adopted, the opposite result could be expected, with higher amounts of $\mathrm{P}$ available in the areas under NT, due to the possibility of smaller nutrient adsorption in the topsoil caused by the coating of adsorption sites of soil particles by organic radicals (Pauletti, 2009). However, these results can be explained by the greater soil variability under no-tillage system, caused by the application of phosphate fertilizer in the furrow, without subsequent soil tillage, inducing greater horizontal and vertical $\mathrm{P}$ variability in the soil and reflecting lower nutrient contents as a result of the sampling process (Machado et al., 2007). Anghinoni (2007) recommends a minimum of 20 simple samples for the NT to obtain a composite sample, in order to allow greater representation in the sampling process. When studying the spatial variability of soil chemical attributes in areas under no-tillage to establish a minimum number of simple samples per sampling point, Oliveira (2017) suggests 
collecting more than 12 subsamples to constitute a composite sample in sampling process in areas under NT, when equipment such as press auger or screw is used. According to the author, $\mathrm{P}$ presented the highest variability among the evaluated attributes, requiring a very high number of subsamples to represent the state of availability in the soil and to ensure greater reliability of the results.

Table 4. Stocks of $\mathrm{P}, \mathrm{K}, \mathrm{Ca}$ and $\mathrm{Mg}$ in an Oxisol under different systems of soil use in the municipality of Paragominas, Pará, Brazil

\begin{tabular}{|c|c|c|c|c|}
\hline \multirow{2}{*}{ Depth (cm) } & \multicolumn{4}{|c|}{ Management system of soil } \\
\hline & CT6 & NT3 & NT4 & NT7 \\
\hline & \multicolumn{4}{|c|}{ Stocks of $\mathrm{P}\left(\mathrm{kg} \mathrm{ha}^{-1}\right)$} \\
\hline $0-10$ & $33.71 \mathrm{a}$ & $18.42 \mathrm{~b}$ & $18.77 \mathrm{~b}$ & $19.11 \mathrm{~b}$ \\
\hline $10-20$ & $24.45 \mathrm{a}$ & $13.02 \mathrm{~b}$ & $12.07 \mathrm{~b}$ & $17.78 \mathrm{~b}$ \\
\hline $20-40$ & $29.32 \mathrm{a}$ & $14.97 \mathrm{~b}$ & $16.84 \mathrm{~b}$ & $15.59 \mathrm{~b}$ \\
\hline \multirow[t]{2}{*}{$0-40$} & $87.47 \mathrm{a}$ & $46.41 \mathrm{~b}$ & $47.67 \mathrm{~b}$ & $63.71 \mathrm{ab}$ \\
\hline & \multicolumn{4}{|c|}{ 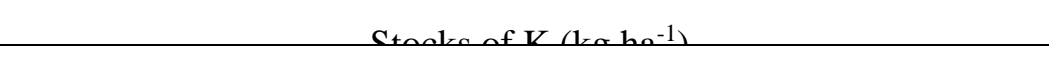 } \\
\hline $0-10$ & $178 \mathrm{a}$ & $188 \mathrm{a}$ & $180 \mathrm{a}$ & $221 \mathrm{a}$ \\
\hline $10-20$ & $150 \mathrm{ab}$ & $130 \mathrm{bc}$ & $125 \mathrm{c}$ & $169 \mathrm{a}$ \\
\hline $20-40$ & $249 \mathrm{ab}$ & $216 b$ & $234 a b$ & $271 \mathrm{a}$ \\
\hline \multirow[t]{2}{*}{$0-40$} & $577 \mathrm{ab}$ & $535 \mathrm{~b}$ & $538 \mathrm{~b}$ & $725 \mathrm{a}$ \\
\hline & \multicolumn{4}{|c|}{ Stocks of $\mathrm{Ca}\left(\mathrm{kg} \mathrm{ha}^{-1}\right)$} \\
\hline $0-10$ & $509 \mathrm{c}$ & $559 \mathrm{bc}$ & $588 \mathrm{~b}$ & $857 \mathrm{a}$ \\
\hline $10-20$ & $390 \mathrm{~b}$ & $483 \mathrm{~b}$ & $483 \mathrm{~b}$ & $745 \mathrm{a}$ \\
\hline $20-40$ & $602 c$ & $747 \mathrm{~b}$ & $843 \mathrm{~b}$ & $1237 \mathrm{a}$ \\
\hline \multirow[t]{2}{*}{$0-40$} & $1501 \mathrm{c}$ & $1790 \mathrm{~b}$ & $1915 \mathrm{~b}$ & $2838 \mathrm{a}$ \\
\hline & \multicolumn{4}{|c|}{ Stocks of $\mathrm{Mg}\left(\mathrm{kg} \mathrm{ha}^{-1}\right)$} \\
\hline $0-10$ & $113 \mathrm{~b}$ & $120 \mathrm{~b}$ & $124 \mathrm{~b}$ & $163 \mathrm{a}$ \\
\hline $10-20$ & $88 \mathrm{~b}$ & $106 \mathrm{~b}$ & $104 \mathrm{~b}$ & $151 \mathrm{a}$ \\
\hline $20-40$ & $146 \mathrm{c}$ & $171 \mathrm{bc}$ & $185 \mathrm{~b}$ & $263 \mathrm{a}$ \\
\hline $0-40$ & $347 \mathrm{c}$ & $397 \mathrm{~b}$ & $413 b$ & $578 \mathrm{a}$ \\
\hline
\end{tabular}


*Means followed by the same letter in the same line are not different by the multiple comparison test of Bonferroni at 5\% probability level.

In the areas under NT, a trend in the increase in the nutrient quantities as a function of the adoption period was observed with an increase of up to $33 \%$ of available $\mathrm{P}$ at seven years (NT7) after the system implementation, in relation to the average value at four years of implementation (NT4). According to Nicolodi et al. (2008), the relationships built in the soil over the cultivation period in NT are preserved and enriched by the diversity of species used in the rotation, favoring not only the chemical conditions that are altered and improved it, but also the physical and biological soil conditions.

Although no significant difference in exchangeable $\mathrm{K}$ stocks between the use systems was found in the topsoil $(0-10 \mathrm{~cm})$, there was a tendency for an increase in the amount at seven years of NT implementation (Table 4). Santos \& Tomm (2003) and Freitas (2011) found higher levels of $\mathrm{K}^{+}$in NT and such results may be the result of the nutrient release occurring in larger quantities in the first soil layers, due to the accumulation of plant residues from previous crops. This may depend on the amount of nutrients accumulated in the cover crop phytomass, the adoption time of the NT and the agro-climatic factors (Lopes et al., 2004).

Stocks of exchangeable in the first 40-cm depth were influenced by the use systems, with an increase in the amount of exchangeable $\mathrm{K}$ as a function of the NT adoption period (Table 4), with a $35 \%$ increase in the amount of nutrient obtained at seven years of adoption of the system $\left(725 \mathrm{~kg} \mathrm{ha}^{-1}\right)$, compared to the value obtained at the four years of adoption $(538 \mathrm{~kg}$ $\left.\mathrm{ha}^{-1}\right)$.

At 0-40 $\mathrm{cm}$ depth, exchangeable $\mathrm{Ca}$ and $\mathrm{Mg}$ stocks showed similar behavior to the other nutrients, in which the amounts of these bases in NT were significantly higher at seven years after their implantation (Table 4). The values of these nutrients in treatments NT3 and NT4 did not differ significantly from each other, which were significantly higher than CT6. These results may be the reflection of the lack of soil tillage and greater contribution of organic matter in the NT (Lopes et al., 2007; Dalchavion et al., 2012). The movement of Ca and Mg in the soil depth is attributed to the formation of complexes with organic binders originated from the plant residues in the topsoil in NT. Such complexes have negative or zero charges, and since the soil exchange complex has predominantly negative charges, the retention of these molecules is low (Ziglio et al., 1999; Steiner et al., 2011). According to Moreira et al. (2001), as cultivation period under no-tillage system increases, the distribution of $\mathrm{Ca}, \mathrm{Mg}$ and values of $\mathrm{pH}$ and base saturation $(\mathrm{V} \%)$ in the soil profile become more homogeneous.

Regarding soil acidity, regardless of depth, at seven years after the implementation of NT (NT7), the largest increase in soil $\mathrm{pH}$ (water) value was observed. Such value was significantly higher than the others (Table 5). The $\mathrm{pH}$ (water) values between NT3, NT4 and CT6 did not differ significantly from each other. These results are the outcome from management performed in the NT, with modifications resulting from the increased period in use of the area, such as the absence of soil tillage and the deposition of cultural residues (Carvalho et al., 2009a; Freitas, 2011; Rodrigues et al., 2017). In the no-tillage system, the high concentration of organic acids can effectively contribute to the complexation of most 
aluminum in solution, as a result of lower concentration of toxic species $\left(\mathrm{Al}^{3+}\right.$ and $\left.\mathrm{AlOH}^{2+}\right)$ and higher concentration of Al complexed with organic ligands (Salet et al., 1999; Zambrosi et al., 2007). In addition, soil-soluble cations resulting from the deposition of organic residues on the soil surface may promote an increase in soil $\mathrm{pH}$ and a decrease in exchangeable $\mathrm{Al}$ (Franchini et al., 1999; Meda et al., 2001). On the other hand, the lower levels of exchangeable bases in CT6 treatment (lower V\% values) may have induced the lower rise in soil pH value (Dalchavion et al., 2012).

Table 5. Values of $\mathrm{pH}, \mathrm{CEC}$ and $\mathrm{V} \%$ in an Oxisol under different system of soil use in the municipality of Paragominas, Pará, Brazil

\begin{tabular}{|c|c|c|c|c|}
\hline \multirow{2}{*}{ Depth (cm) } & \multicolumn{4}{|c|}{ Management system of soil } \\
\hline & CT6 & NT3 & NT4 & NT7 \\
\hline & \multicolumn{4}{|c|}{$\mathrm{nH}$ in water } \\
\hline $0-10$ & $6,0 \mathrm{~b}$ & $6,2 \mathrm{~b}$ & $6,2 \mathrm{~b}$ & $6,6 \mathrm{a}$ \\
\hline $10-20$ & $5,7 \mathrm{~b}$ & $5,9 \mathrm{~b}$ & $5,9 \mathrm{~b}$ & $6,4 \mathrm{a}$ \\
\hline \multirow[t]{2}{*}{$20-40$} & $5,6 \mathrm{~b}$ & $5,7 \mathrm{~b}$ & $5,7 \mathrm{~b}$ & $6,2 \mathrm{a}$ \\
\hline & \multicolumn{4}{|c|}{$\mathrm{CEC}\left(\mathrm{cmol}_{\mathrm{c}} \mathrm{dm}^{-3}\right)$} \\
\hline $0-10$ & $9 \mathrm{~b}$ & $9 \mathrm{~b}$ & $10 \mathrm{ab}$ & $11 \mathrm{a}$ \\
\hline $10-20$ & $8 \mathrm{~b}$ & $9 \mathrm{ab}$ & $9 \mathrm{a}$ & $10 \mathrm{a}$ \\
\hline \multirow[t]{2}{*}{$20-40$} & $7 \mathrm{c}$ & $8 \mathrm{~b}$ & $9 \mathrm{a}$ & $9 \mathrm{a}$ \\
\hline & \multicolumn{4}{|c|}{ V\% } \\
\hline $0-10$ & $55 \mathrm{~b}$ & $61 \mathrm{~b}$ & $58 \mathrm{~b}$ & $76 \mathrm{a}$ \\
\hline $10-20$ & $44 \mathrm{~b}$ & $49 \mathrm{~b}$ & $48 \mathrm{~b}$ & $66 a$ \\
\hline $20-40$ & $40 \mathrm{~b}$ & $43 \mathrm{~b}$ & $44 \mathrm{~b}$ & $60 \mathrm{a}$ \\
\hline
\end{tabular}

*Means followed by the same letter are not different from each other by the test of Kruskall Wallis $(\mathrm{p}<0.05)$.

The values of V\% and CEC increased as a function of NT adoption period (Table 5) and are directly related to the contents of $\mathrm{K}^{+}, \mathrm{Ca}^{2+}$ and $\mathrm{Mg}^{2+}$ on the surface, by the higher soil coverage and smaller aluminum contents and lower acidity provided by the system (Freitas, 
2005; Muzilli, 2006; Cavalcante et al., 2007). In general, effective CEC increases as soil acidity is corrected due to rise in $\mathrm{pH}$ (Volkweiss, 1989). However, Nicolodi et al. (2008) consider that there is no effective CEC variation under NT due to $\mathrm{pH}$ variation in the soil. Maintaining high soil $\mathrm{CO}$ concentration is critical in tropical soils because of its importance for soil fertility and cation exchange capacity.

Overall, an increase was observed in V\% indexes in the soil depth mainly at seven years of cultivation under NT (NT7) compared to the values found in soil cultivated under CT. These results are associated with the highest $\mathrm{Ca}$ and $\mathrm{Mg}$ contents found in the 10-20 cm and 20-40 cm depths. According to Franchini et al. (2003), in systems with high input of organic waste, the polyvalent cations $(\mathrm{Ca}, \mathrm{Mg}$ and $\mathrm{Al})$ are preferentially leached in the soil profile, which may be due to the null or negative charges of the organic complexes formed between the organic anions released from the plant residues and polyvalent cations.

\subsection{Correlation Between C Stocks and Soil Chemical Attributes}

According to the results of Pearson's correlation analysis, for the $0-40 \mathrm{~cm}$ depth, provided that the equivalent significance limit at $\mathrm{p}<0.05$, it was observed that in the area under CT as well as in NT, there was no correlation between the CS and PS in the soil (Table 6), which may be justified by the low nutrient mobility in the soil depth, considering that the P conteNT in this soil are originally low. In addition, the main source of $\mathrm{P}$ in these systems comes from the application of phosphate fertilizers, which concentrate on the surface, reducing the nutrient content in soil depth (Lourente et al., 2010).

Table 6. Pearson correlation coefficient between carbon stock (CS), nutrient stock and chemical attributes at a depth of 0-40 $\mathrm{cm}$ of a dystrophic Yellow Oxisol under different soil management systems

\begin{tabular}{lcccc}
\hline & \multicolumn{4}{c}{ Management system of soil } \\
\cline { 2 - 5 } Relation & CT6 & NT3 & NT4 & NT7 \\
\cline { 2 - 5 } CS x SP & $0.32(0.31)$ & $0.19(0.55)$ & $0.17(0.60)$ & $0.20(0.53)$ \\
CS x SK & $0.45(0.15)$ & $0.96(0.00)$ & $0.86(0.00)$ & $0.62(0.03)$ \\
CS x SCa & $0.54(0.07)$ & $0.91(0.00)$ & $0.77(0.00)$ & $0.69(0.01)$ \\
CS x SMg & $0.46(0.13)$ & $0.90(0.00)$ & $0.80(0.00)$ & $0.77(0.00)$ \\
CS x pH(water $)$ & $0.04(0.89)$ & $-0.02(0.94)$ & $-0.23(0.47)$ & $-0.43(0.17)$ \\
CS x CTC & $-0.16(0.62)$ & $-0.48(0.11)$ & $-0.29(0.36)$ & $-0.43(0.16)$ \\
CS x V\% & $0.04(0.89)$ & $0.00(0.99)$ & $-0.19(0.55)$ & $-0.39(0.21)$ \\
\hline
\end{tabular}


CT6 = conventional system at six year cropping; NT3, NT4 and NT7 = no-tillage system with three, four and seven years of adoption, respectively; SP, SK, SCa and SMg = Stocks of $\mathrm{P}, \mathrm{K}, \mathrm{Ca}$ and $\mathrm{Mg}$, respectively; valor between parentheses = p-value. The correlations consider the values regarding the $0-10 \mathrm{~cm}, 10-20 \mathrm{~cm}$ and $20-40 \mathrm{~cm}$ layers.

By considering the benefits of NT, with higher accumulation of organic matter and, consequently, lower amounts of $\mathrm{P}$ in adsorbed forms (Nunes et al., 2011), the lack of correlation of these soil attributes can also be explained by the greater variability of $\mathrm{P}$ in this system, caused by the application of phosphate fertilizer and the non-plowed soil, reflecting in lower levels of nutrient in the deeper layers (Oliveira, 2017).

The stocks of $\mathrm{K}, \mathrm{Ca}$ and $\mathrm{Mg}$ showed a significant positive correlation with the CS, only in the areas under NT, regardless of the adoption period of the system, probably caused by the mobilization of these nutrients in the soil profile, which followed the changes in the organic matter contents up to $40 \mathrm{~cm}$ of depth. These results demonstrate the beneficial effects of NT on soil profile formation, leading to an initial increase of organic matter on the soil surface, promoting the movement of exchangeable bases in the soil depth through the formation of complexes with organic ligands originated from the plant residues in the soil surface layer, reducing the retention of these molecules and allowing mobilization of these bases to deeper horizons, with enhancement of chemical attributes in the root environment (Steiner et al., 2011; Freitas et al., 2011). The increase in these exchangeable cations in the soil depth promotes greater root growth and consequently increases in the organic matter in the soil profile. In an area under minimum cultivation system in the northern Mato Grosso state, in the Brazilian Amazon biome, Rodrigues et al. (2017) also obtained high correlations between soil $\mathrm{K}, \mathrm{Ca}$ and $\mathrm{Mg}$ levels with those of soil organic matter up to $40 \mathrm{~cm}$ depth, whose results were related to the ability of organic matter to maintain soil fertility.

Regardless of the soil management system, no significant correlations were observed between the CS and the attributes $\mathrm{pH}$ (water), CEC and V\%, considering the 0-40 cm depth (Table 6). These results may be due to the calculations used to estimate the carbon stock that considered the thickness of $20 \mathrm{~cm}$ for the $20-40 \mathrm{~cm}$ layer, which is as much as twice as the previous ones, which did not occur for the referred attributes, as average values were considered for the mentioned layer.

However, considering only the values used for the $0-10 \mathrm{~cm}$ and $10-20 \mathrm{~cm}$ layers, which have the same thickness, a positive correlation was observed between the $\mathrm{CS}$ and $\mathrm{pH}$ (water) for the NT3 ( $r=0.81 ; p=0.02)$, NT4 $(r=0.78 ; p=0.02)$ and NT7 $(r=0.79 ; p=0.02)$. It was also verified that the SC correlated positively with the $\mathrm{V} \%$ values in the same layers, presenting correlation coefficients equivalent to $0.91(\mathrm{p}=0.001), 0.85(\mathrm{p}=0.01)$ and $0.73(\mathrm{p}$ $=0.04$ ) for treatments NT3, NT4 and NT7, respectively. This indicates that the introduction of conservation management practices, such as the non-tillage system, influenced the soil CS and had direct and indirect consequences on other soil chemical attributes, with improvements in soil fertility. 


\section{Conclusion}

In areas under no-tillage system, carbon stock values in the $0-10 \mathrm{~cm}, 10-20 \mathrm{~cm}$ and $20-40 \mathrm{~cm}$ layers are greater than those under conventional tillage system.

In the no-tillage system, the increase in soil carbon stock is caused by the increase in adoption period with smaller increments in the third and fourth year. At seven years of adoption, a greater increase was found in carbon stock, with value about $36 \%$ higher than the conventional system.

In the cultivated area under conventional system (CT6), the stocks of P in the 0-40 cm layer are higher than under no-tillage system.

At seven years of NT implementation, the stocks of $\mathrm{K}, \mathrm{Ca}$ and $\mathrm{Mg}$ are higher than in the conventional system.

Carbon stocks have a significant positive correlation with $\mathrm{K}, \mathrm{Ca}$ and $\mathrm{Mg}$ stocks in areas under NT, regardless of the system adoption period, up to $40 \mathrm{~cm}$ of soil depth.

\section{References}

AL-Kaisi, M. M., \& Yin, X. (2005). Tillage and crop residue effects on soil carbon and carbon dioxide emission in corn-soybean rotation. Journal of Environmental Quality, 34, 437-445. https://doi.org/10.2134/jeq2005.0437

Anghinoni, I. Fertilidade do solo e seu manejo em sistema plantio direto. In: NOVAIS et al. Fertilidade do solo. Viçosa - MG, Sociedade Brasileira de Ciência do Solo, 2007. 873-928.

Anghinoni, I., \& Salet, R. L. (1998). Amostragem do solo e as recomendações de adubação e calagem no sistema plantio direto. In: Nuernberg, N. J. ed. Conceitos e fundamentos do sistema plantio direto. Lages, Sociedade Brasileira de Ciência do Solo/Núcleo Regional Sul, 27-52.

Assis, R. L., \& Lanças, K. P. (2005). Avaliação dos atributos físicos de um Nitossolo Vermelho distroférrico sob sistema plantio direto, preparo convencional e mata nativa. Revista Brasileira de Ciência do Solo, 29(4), 515-522, https://doi.org/10.1590/S0100-06832005000400004

Bastos, T. X. et al. (2005). Características agroclimáticas do município de Paragominas - PA. Embrapa Amazônia Oriental. Belém - PA. 2005. Available in: https://www.embrapa.br/busca-de-publicacoes/-/publicacao/407905/caracteristicas-agroclimat icas-do-municipio-de-paragominas

Bianconi, A. et al. (2008). Transformação de dados e implicações da utilização do teste de Kruskal- wallis em pesquisas agroecológicas. Revista de Ecotoxicologia e Meio Ambiente, 18, 27-34. https://doi.org/10.5380/pes.v18i0.13374

Carvalho, J. L. N. et al. (2009a). Carbon sequestration in agricultural soils in the Cerrado region of the Brazilian Amazon. Soil Tillage Research. 103, 342-349. https://doi.org/10.1016/j.still.2008.10.022 
Carvalho, J. L. N. et al. (2009b). Conversion of Cerrado into agricultural land in the south-western Amazon: carbon stocks and soil fertility. Scienc Agricultual (Piracicaba, Braz.), 66(2), 233-241. https://doi.org/10.1590/S0103-90162009000200013

Cavalcante, E. G. S. et al. (2007). Variabilidade espacial de MO, P, K, e CTC do solo sob diferentes usos e manejos. Ciência Rural, Santa Maria - RS, 37(2). https://doi.org/10.1590/S0103-84782007000200015

Cerri, C. C. et al. (2010). Greenhouse gas mitigation options in Brazil for land-use change, livestock and agriculture. Scientia Agricola, 67(1), 102-116. https://doi.org/10.1590/S0103-90162010000100015

Chaves, S. S. de F. (2014). Dinâmica do carbono no solo sob diferentes usos da terra em Paragominas, PA. Dissertação (Mestrado em Fitotecnia) - Escola Superior de Agricultura Luiz de Queiroz, Universidade de São Paulo, Piracicaba. https://doi.org/10.11606/D.11.2014.tde-29052014-171038

Costa, F. S. et al. (2014). Aumento de matéria orgânica num latossolo bruno em plantio direto. Ciencia Rural, Santa Maria-RS, 34(2), 587-589. https://doi.org/10.1590/S0103-84782004000200041

Dalchavion, F. C. et al. (2012). Variabilidade espacial de atributos da fertilidade de um Latossolo Vermelho Distroférrico sob Sistema de Plantio Direto. Revista Ciência Agronômica, Fortaleza-CE, 43(3), 453-461. https://doi.org/10.1590/S1806-66902012000300006

Deon, D. S. (2013). Mudança de uso da terra e impacto na matéria orgânica do solo em dois locais no Leste da Amazônia. Tese de Doutorado. Universidade de São Paulo. 2013.

Ellert, B. H., \& Bettany, J. R. (1995). Calculation of organic matter and nutrients stored in soils under contrasting management regimes. Canadian Journal of Soil Science, 75, 529-538. Available in: https://www.nrcresearchpress.com/doi/pdfplus/10.4141/cjss95-075. Accessed in: June 16, 2018. https://doi.org/10.4141/cjss95-075

Fontana, A. et al. (2006). Atributos de fertilidade e frações húmicas de um Latossolo Vermelho no Cerrado. Pesquisa Agropecuária Brasileira, 41(5), 847-853. Available in: https://seer.sct.embrapa.br/index.php/pab/article/view/7215. Accessed in: march 24, 2019. https://doi.org/10.1590/S0100-204X2006000500018

Fontes, J. R. A., et al. (2012). Manejo do solo e modificações de comunidades de plantas daninhas em culturas de grãos no estado do Amazonas. Manaus: Embrapa Amazônia Ocidental, 27p. (Embrapa Amazônia Ocidental. Documentos, 95), 2012. Available in: https://www.infoteca.cnptia.embrapa.br/bitstream/doc/949584/1/Doc95A5.pdf. Accessed in: march 02, 2019.

Franchini, J. C. et al. (2003). Organic composition of green manure during growth and its effect on cátion mobilization in an acid Oxisol. Comm. Soil Science and Plant Analysis, 34, 2045-2058. https://doi.org/10.1081/CSS-120023237

Franchini, J. C. et al. (1999). Alterações químicas em solos ácidos após a aplicação de 
resíduos vegetais. Revista Brasileira de Ciência do Solo, Viçosa, 23, 533-542. https://doi.org/10.1590/S0100-06831999000300006

Freitas, L. de S. et al. (2011). Variação de atributos químicos de dois Latossolos Amarelos sob diferentes sistemas de manejo nos municípios de Redenção e Paragominas - PA. 176p. Tese (Doutorado) - Universidade Federal Rural da Amazônia - UFRA, Belém, 2011. Available in: https://www.infoteca.cnptia.embrapa.br/bitstream/doc/949584/1/Doc95A5.pdf. Accessed in: March 02, 2019.

Freitas, P. L. (2005). Sistema Plantio Direto: Conceitos, Adoções e Fatores limitantes. Comunicado Técnico Embrapa, Rio de Janeiro, RJ, p.3, Dezembro. Available in: https://ainfo.cnptia.embrapa.br/digital/bitstream/item/89433/1/comtec31-2005-plantio-direto. pdf. Accessed in: April 26, 2019.

Guedes, E. M. S. (2009). Atributos químicos e físicos de um Latossolo Amarelo argiloso e produção de soja em sistemas de manejo, no Município de Paragominas/PA. Belém, 2009. 75f.:il. Dissertação (Mestrado em Agronomia) - Universidade Federal Rural da Amazônia.

Guedes, E. M. S. et al. (2012). Impacts of different management systems on the physical quality of an Amazonian Oxisol. Revista Brasileira de Ciência do Solo, 36(4), 1269-1278. https://doi.org/10.1590/S0100-06832012000400021

Lopes, A. S. et al. (2004). Sistema plantio direto: Bases para o manejo da fertilidade do solo. ANDA, 110p. São Paulo.

Lopes, A. S., \& Guilherme, L. R. G. (2007). Fertilidade do solo e produtividade agrícola. In: Machado, L. O. et al. Variabilidade espacial de atributos químicos do solo em áreas sob sistema plantio convencional. Revista Brasileira de Ciência do Solo, 31(03), 591-599. https://doi.org/10.1590/S0100-06832007000300019

Lourente, E. R. P. et al. (2010). Rotação de culturas e relações com atributos químicos e microbiológicos do solo e produtividade do milho. Seminario: Ciências Agrárias, Londrina, 31(4), 829-842, https://doi.org/10.5433/1679-0359.2010v31n4p829

Machado, P. L. O. de A., \& Silva, C. A. (2001). Soil management under no-tillage systems in the tropics with special reference to Brazil. Nutrient Cycling in Agroecosystems, 61, 119-130. https://doi.org/10.1007/978-94-017-2172-1_12

Maia S. M. F. et al. (2010). Changes in soil organic storage under different agricultural management systems in the Southwest Amazon Region of Brazil. Soil \& Tillage Research, 106(2), 177-184. https://doi.org/10.1016/j.still.2009.12.005

Mascarenhas, A. R. P., Sccoti, M. S. V., Melo, R. R., de Oliveira Corrêa, F. L., de Souza, E. F. M., Andrade, R. A., ... Müller, M. W. (2017). Atributos físicos e estoques de carbono do solo sob diferentes usos da terra em Rondônia, Amazônia Sul-Ocidental. Pesquisa florestal brasileira, 37(89), 19-27. https://doi.org/10.4336/2017.pfb.37.89.1295

Meda, A. R. et al. (2001). Alleviating soil acidity through plant organic compounds. Brazilian Archives of Biology and Technology, 44(2), 185-189. Available in: 
https://doi.org/10.1590/S1516-89132001000200012

Mielniczuk, J. et al. (2001). Calagem em sistema de semeadura direta e efeitos sobre a acidez do solo, disponibilidade de nutrientes e produtividade de milho e soja. Revista Brasileira de Ciência do Solo, Viçosa - MG, 25, 71-8. https://doi.org/10.1590/S0100-06832001000100008

Muzilli, O. (2006). Manejo do solo em sistema plantio direto. Londrina, IAPAR.

Nicolodi, M. et al. (2008). Indicadores da acidez do solo para recomendação de calagem no sistema plantio direto. Revista brasileira de ciencia do solo. Campinas, 32(1), 237-247. https://doi.org/10.1590/S0100-06832008000100023

Nunes, R. S. et al. (2011). Distribuição de fósforo no solo em razão do sistema de cultivo e manejo da adubação fosfatada. Revista Brasileira de Ciência do Solo, Viçosa, 35, 877-888. https://doi.org/10.1590/S0100-06832011000300022

Oliveira, D. M. (2017). Número de amostras e variabilidade espacial de atributos químicos do solo em sistema plantio direto. Universidade Federal de Santa Maria, RS. Dissertação (Mestrado). 61p.

Pauletti, V. et al. (2009). Atributos químicos de um latossolo bruno sob sistema plantio direto em função, da estratégia de adubação e do método de amostragem do solo. Revista Brasileira de Ciência do Solo, Viçosa-MG. $\quad 33, \quad$ 581-590. https://doi.org/10.1590/S0100-06832009000300011

Petter, F. A. et al. (2017). Carbon stocks in oxisols under agriculture and forest in the southern Amazon of Brazil. Geoderma regional, 11, 53-61. https://doi.org/10.1016/j.geodrs.2017.09.001

Pragana, R. B. et al. (2012). Qualidade física de latossolos amarelos sob plantio direto na região do cerrado piauiense. Revista Brasileira de Ciência do Solo, Viçosa-MG, 36, 1591-1600. https://doi.org/10.1590/S0100-06832012000500023

Rangel, O. J. P. et al. (2007). Estoque e frações da matéria orgânica de latossolo cultivado com cafeeiro em diferentes espaçamentos de plantio. Revista Brasileira de Ciência do solo. https://doi.org/10.1590/S0100-06832007000600013.

Rodrigues, M. et al. (2017). Changes in chemical properties by use and management of an oxisol in the amazon biome. Revista Caatinga, Mossoró, 30(2), 278-286. https://doi.org/10.1590/1983-21252017v30n202rc

Rodrigues, T. E. et al. (2003). Caracterização e Classificação dos Solos do Município de Paragominas, Estado do Pará. Belém: Embrapa Amazônia Oriental. p.64.

Rossetti, K.V., \& Centurion, J. F. (2015). Estoque de carbono e atributos físicos de um latossolo em cronossequencia sob diferentes manejos. Revista Brasileira de Engenharia $\begin{array}{llll}\text { Agrícola } & e & \text { Ambiental, } & \text { 252-258. }\end{array}$ https://doi.org/10.1590/1807-1929/agriambi.v19n3p252-258

SÁ, et al. (2017). Low-carbon agriculture in South America to mitigate global climate change 
and advance food security. Environment international, 98, 102-112. https://doi.org/10.1016/j.envint.2016.10.020

SÁ, J. C. M. et al. (2004). O plantio direto como base de produção. Revista Plantio Direto, 84, 45-61.

Salet, R. L. et al. (1999). Atividade do alumínio na solução de solo do sistema plantio direto. Revista Científica Unicruz, Cruz Alta, 1(1), 9-13.

Santos, H. P., \& Tomm, G. O. (2003). Disponibilidade de nutrientes e teor de matéria orgânica em função de sistemas de cultivo e de manejo de solo. Ciência Rural, 33(3), 477-486. https://doi.org/10.1590/S0103-84782003000300013

Santos, H. G. et al. (2013). Sistema brasileiro de classificação de solos. 3.edição revisado e ampliada Brasília: Embrapa, 353p.

Silva, C. A., Machado, P. L. O. A. (2000). Seqüestro e emissão de carbono em ecossistemas agrícolas: Estratégias para o aumento dos estoques de matéria orgânica em solos tropicais. Rio de Janeiro, Embrapa Solos, 2000. 23p. (Documentos, 19). Available in: file://C:/Users/Edilson\%20Brasil/Downloads/Sequestroeemissao.pdf. Accessed in: January 29, 2019.

Silva, M. L. N. et al. (2004). Aumento de matéria orgânica num latossolo bruno em plantio direto. Ciência Rural, 34(2), 587-589. https://doi.org/10.1590/S0103-84782004000200041

Siqueira Neto, M. et al. (2009). Carbono total e atributos químicos com diferentes usos do solo no Cerrado. Acta Scienc, Agron. (Online), Maringá, 31(4), 709-717. https://doi.org/10.4025/actasciagron.v31i4.792

Steiner, F. et al. (2011). Atributos químicos do solo em diferentes sistemas de culturas e fontes de adubação. Global Science and Technology, 4(1). Available in: https://rv.ifgoiano.edu.br/periodicos/index.php/gst/article/view/287. Accessed in: April 26, 2019.

Tavakkoli, E. et al. (2015). The effect of cation-anion interactions on soil $\mathrm{pH}$ and solubility of organic carbon. European Journal of Soil Science, 66(6), 1054-1062. https://doi.org/10.1111/ejss.12294

Teixeira, P. C. (2017). Manual de métodos de análise de solos. 3.ed. rev. ampl. Rio de Janeiro: Embrapa Solos. 573p.

Tormena, C. A. et al. (2004). Propriedades físicas e taxa de estratificação de carbono orgânico num Latossolo Vermelho após dez anos sob dois sistemas de manejo. Revista Brasileira Ciência do Solo, Viçosa-MG, $\quad$ 28(6), https://doi.org/10.1590/S0100-06832004000600011

Veloso, H. P. et al. (1991). Classificação da vegetação brasileira adaptada a um sistema universal. Departamento de Recursos Naturais e Estudos Ambientais / IBGE, Rio de Janeiro.

Volkweiss, S. J. Química da acidez dos solos. In: Kaminski, J.; Volkweiss, J. \& Zambrosi, F. 
C. B. et al. (2007). Aplicação de gesso agrícola e especiação iônica da solução de um Latossolo sob sistema plantio direto. Ciência Rural, Santa Maria, 37(1), 110-117.

Zar, J. H. (1999). Biostatistical analysis. 4thed. New Jersey: Prentice Hall Inc., 938p. https://doi.org/10.1590/S0103-84782007000100018

Zambrosi, F. C. B. et al. (2007). Teores de alumínio trocável e não trocável após calagem e gessagem em Latossolo sob plantio direto. Bragantia, 66(3), 487-495. https://doi.org/10.1590/S0006-87052007000300016

Ziglio, C. M. et al. (1999). Formas orgânicas e inorgânicas de mobilização do cálcio no solo. Brazilian Archives of Biology and Technology, 42(2), 257-262. https://doi.org/10.1590/S1516-89131999000200016

\section{Copyright Disclaimer}

Copyright for this article is retained by the author(s), with first publication rights granted to the journal.

This is an open-access article distributed under the terms and conditions of the Creative Commons Attribution license (http://creativecommons.org/licenses/by/4.0/). 